\title{
Poor Municipal Spending for Infrastructure Development and Gap for Investment: A Case of Bangladesh
}

\author{
Mohammad Hossain ${ }^{1,2}$ \\ ${ }^{1}$ Graduate School of Economics, Yamaguchi University, Yamaguchi, Japan \\ ${ }^{2}$ Ministry of Public Administration, Government of the People's Republic of Bangladesh, Dhaka, Bangladesh \\ Correspondence: Mohammad Hossain, Office of the Upazila Nirbahi Officer, Daganbhuiyan, Feni, 3920, \\ Bangladesh. Tel: 88-017-6461-0173.E-mail: mhttw1538@yahoo.com
}

Received: February 25, 2013

Accepted: March 18, 2013

Online Published: May 16, 2013

doi:10.5539/ijbm.v8n11p27

URL: http://dx.doi.org/10.5539/ijbm.v8n11p27

\begin{abstract}
The study aims at assessing (Bangladeshi) municipal financial capabilities in meeting growing demands for infrastructure facilities and other services. Determining municipal financial capacities is important mainly because the factors such as around 3.1 percent (Note 1) annual urbanization growth, 40-50 percent (Note 2) urban service gap and creation of new urban bodies put tremendous pressure on municipal authorities to meet the growing demand for infrastructure facilities and citizenry services. By analyzing sampled municipal annual budget documents along with urban population data, and questionnaire survey, the study finds that municipalities are as poorly capable as to spend less than US\$10 per person annually. The study also finds 18-97 percent shortage of estimated transfer revenues, which are generally being used for building infrastructure facilities that literally requires huge capital investment. So vacuum for investment is found. Around 70 percent respondents interviewed are dissatisfied with the service qualities and quantities they receive. Thus, the study suggests that government should give immediate attention to find alternate financing options for investment-hungry municipal infrastructure development sector.
\end{abstract}

Keywords: Municipal infrastructure facilities demand, central transfers, urban growth, own source revenue

\section{Introduction}

Municipalities in Bangladesh cannot fulfill the increasing demands for infrastructure facilities and other services (Siddique, 2005). Because rapid urbanization with about 3.1 percent urban growth, prevailing 40-50 percent urban service deficits, government recent steps toward functional decentralization and creating new urban bodies, demand for infrastructure facilities increases (UNICEF, 2010; Choudhury, 2004). Again, own-source revenues are so scant as to create enough funds for growing infrastructure development. Transfer revenues are proved inadequate and instable because of government incapacity to allocate adequate funds. This situation is recently aggravated by donor countries unwillingness to provide grants and concessionary loans (Billand, 2005). Municipal spending capabilities are, thus, very poor to meet widening infrastructure needs. In addition, continuous fiscal deficits with poor economic growth and other investment priorities such as energy and transportation investment have significantly limited central government transfers to municipalities.

Using sampled municipal annual budget data, urban population growth data and questionnaire survey, the study estimates that infrastructure facilities demands are remarkably growing, while the funds for infrastructure development are incredibly scant and in real value, to some extent, decreasing because of nearly two-digit inflation. The study finds that the money amount the municipalities spend for infrastructure development and for other services are so slim that infrastructure development greatly hampered by uneven, inadequate and huge shortage of planned revenues. Municipalities, thus, fail to provide necessary infrastructure facilities and other urban amenities with poor spending capacities that actually indicate that there is a big gap for investment. The study also suggests conducting in-depth study to figure out most effective alternative infrastructure financing mechanisms that can best serve the needs of growing infrastructure facilities.

\subsection{Importance of Problem}

The problem as identified above deserves new research to assess municipal financial capabilities as there have no significant studies conducted yet on municipal finance of Bangladesh and very few available data that 
literally can provide with the understanding of currently practiced municipal finance's success and failure ( Fox \& Menon, 2008). In other words, Bangladesh is a developing country that records each year very impressive 3.1 percent urban growth rate and that estimates 83 million urban populations by 2025 that actually will necessitate additional infrastructure development (Bangladesh Bureau of Statistics [BBS], 2001; UNICEF, 2010). Municipalities have many functions to do with very limited resources and that's why research is needed as to assess financial capacities and find financing mechanism to create funds for infrastructure development (Note $3)$.

\subsection{Literature Scanning: Fiscal Decentralization and Infrastructure Development}

Municipal finance is actually the innate part of the fiscal decentralization. As far as efficiency gains and public sector performance concerned, in order to provide public goods and services, fiscal decentralization and shifting assignment of fiscal responsibilities to local level is assumed to be the better option even in the developing countries (Oates 1993; Slater 1997; Bahl 1999). Oates (1993, 1999) argued that public services should be provided by the lowest level of the government for efficiency gains, as tastes, incomes and other needs vary across jurisdictions and local governments are the best one to provide public services in response to local needs and priorities. According to Bird (1993), "So long as there are local variations and in tastes and costs, there is clearly efficiency gains from carrying out public sector activities in as decentralized a fashion as possible". For resource-hungry country as like Bangladesh, efficiency gains are much more crucial in order to fulfill the local people service and infrastructure needs. According to Alm (2010), increased independence of expenditure and revenue assignment should extend local government responsibilities to planning, implementing and maintaining all capital projects. As a result, local government should better be responsible to local people. When local governments do not have provision of providing infrastructure services, they do not feel "ownership" of those capital facilities and thus creates "moral hazard" situations which might lead financial mismanagement and causes infrastructure facilities unsustainable (Alm, 2010). However, fiscal decentralization, as some scholar points, faces some common problems in terms of inefficiency and equity redistribution (Aoki, 2008).

Because rapid urban growth, decentralization, increased local government role in reducing poverty and increased basic service needs, infrastructure development is vital. In developing nations, UN estimated that by 2025 urban people will increase by 2.4 billion that will put extra pressure on municipal authorities to address present and future infrastructure demands. Decentralization that the developing countries make around the world actually means transfer of decision-making power to local people and ultimately makes municipal bodies responsible for arranging infrastructure facilities. In achieving UN Millennium Development Goals (MDG) municipal governments, as vital administrative bodies, should design and implement infrastructure facilities. Democratization is also important for municipalities in planning and financing infrastructure development. In Asia, around half of the urbanized people lack water services and sanitation (Dirie).

\subsection{Bangladesh Chapter}

\subsubsection{Review of Municipal Legal Framework}

Urban Local Government (ULG) in Bangladesh is basically de-concentrated rather than devolved and has no power to legislate. It has powers only by central government legislation. The functions it performs, the revenue sources and expenditure responsibilities it decides are determined by central government legislation. (Note 4) "Thus, in Bangladesh there is a clear patron-client relationship between central government and the local government" (Siddique, 2005). As per Local Government (Paurashava) Act 2009, municipalities are empowered to a larger extent that they can now plan and implement public private partnership projects for infrastructure development that is actually remarkable advancement in terms of legal framework. However, for tax, levy and user fees, laws have given limited power to determination, as new law obligates municipalities to take prior permission for such determinations. Urban areas in Bangladesh are declared by the law (Note 5) based on: a) 75 percent people are engaged in non-agricultural profession b) 33 percent land will be non-farming c) at least 1500 people per square kilometers and d) total population of the area shall not less than 50,000. Municipalities are classified as "Special Category", "A", "B" and "C" based on the amount of revenues they can generate and some other criteria. (Note 6) Tongi is only special category municipality that government thinks to transform it into Tongi City Corporation. Municipal categorization is significant as grants depend on the size of municipality (Siddique, 2005). But regular and almost equal government development grants irrespective of municipality size do not comply with this provision. However, there are some municipalities those do not have even fifty thousand people get same amount of development grants. (Note 7) For accommodating about 41.6 million urban people in Bangladesh, there are two types of urban local government right now: 9 city corporations (Note 8) and 313 municipalities of 'Special Category', 'A', 'B' and 'C' category with scarce urban 
amenities and infrastructure facilities. Only big six city corporations have about 11.58 million people, which constitute $31 \%$ of the total urbanized people and 310 municipalities absorb the remaining $69 \%$ urban people (Note 9).

\subsubsection{Expenditure Responsibilities}

The role of municipal government is crucial in order to make rapidly increased city dwellers' life comfortable and healthy through meeting infrastructure demands and ensuring other service amenities. In pursuit of urban people's well-being, municipal government functional responsibilities in Bangladesh are as follows: (Note 10) i) public health - waste disposal, public toilet, birth-death registration, epidemics control, dispensary and etc., ii) water supply and sewerage system, iii) food and beverage control, iv) animals management—slaughter house etc., v) city or town planning, vi) control over building construction and reconstruction, vii) roads and bridges - construction, maintenance, public transit, lighting, cleanliness etc., viii) public safety-fire, civil defense, flood control, graveyard etc., ix) forestation, parks and recreation, x) education and culture, xi) social welfare, and xii) development planning. Inside these twelve broad heads, there are some 64 categories of functions. However, municipalities in practice cannot perform all these functions because of acute fund crisis.

\subsubsection{Revenue Structure}

Municipal Revenue Items as per Local Government (Paurashava) Act, 2009:

\section{Own-source revenues:}

Taxes:

Property tax and Shared property tax;

Property tax on annual value of buildings and lands;

Tax on transfer of property ownership;

Share (2\%) of Land Development tax collection (Sub-tax on taxes imposed by central government);

Rates on lighting, fire, waste disposal, water, social welfare and etc;

Other taxes:

Tax on profession, business and etc;

Tax on advertisement, cinema, drama and other entertainment;

Tax on non-motorized vehicle (Rikshaw, van etc).

\section{Rates:}

Lighting;

Conservancy;

Fire;

Waste disposal;

Water;

Social welfare.

\section{Non-tax revenues/fees:}

Fees on building construction and reconstruction;

Fees on export from and import to municipal jurisdiction;

Fees on birth, marriage etc;

School fees;

Fees on agricultural fair and display, sports competition and etc;

Fees on license, approvals etc;

Fees on water bodies and ferry terminal;

Toll fees.

\section{Own property's rentals, leases and profits:}

Bus terminal; 
Community centers;

Market rental;

Others.

\section{Intergovernmental transfers:}

Annual Development Allocation;

Special development grants;

Octroi compensation;

Salary compensation grants.

Source: Local Government (Paurashava) Act, 2009; Choudhury, 2004.

Own-source revenue: what type of tax structures and bases is appropriate is still a debatable issue, as argued by Bahl and Bird (2008). For fiscally poorer local government systems, for example, in Bangladesh, Anglo-Sexan model is not effective as central governments are conferred with legislation powers and have fiscal dominance over local government's tax rates and bases (Bahl \& Linn 1992; Alm 2010). However, municipal authorities in Bangladesh are empowered by central government enactments in determining tax rates though local people lack financial resources to pay them. (Note 11) Municipalities in Bangladesh usually generate revenues primarily from own-source and central government transfers. Loan amount is very insignificant. Own-source revenues include taxes, rates and fees. Property taxes are the main own-source revenues, though there are yet enough scopes to collect more own-tax revenues. Rates include water rate, lighting rate, conservancy rate and all other rates. The municipalities have very few assets to add to own-source income. However, some municipalities are entrusted as custodian of assets and properties that central government owns. So, leasing and renting municipal markets are pretty good sources for income.

Central government transfers: Central government transfers for infrastructure development as identified by Alm (2010) are usually to fix vertical and horizontal imbalances between local and national government, to bridge the gap of political divergence, to capitalize the externalities and to attain national objectives at sub-national level. In Bangladesh, central government transfers include government development grants, project specific grants, non-governmental and non-developmental grants. Government development grants are actually Annual Development Grants (ADP) allocated through central government annual budget. Project specific grants are donors' funds and loans that government channels to municipalities as loans and donations. Non-development grants are also disbursed by central government for salary subversion and etc and that amount is very small that follows a static trend over the years. Finally, if local or national affluent persons donate for welfare purpose, that amount goes under non-governmental grants category. The transfer amount often is determined based on specific criteria. However, ADP to finance infrastructure development declines over the years, as such transfers depend on central government fiscal ability that in true sense squeezes (WB, 2007). There are also some limitations of central government transfers as Alm (2010) argued that grants' conditionality contradicts with interchangeability of funds. In addition, local governments very rarely take "ownership" of capital facilities built by central government transfers. In Bangladesh, for example, during 1980 USA ID-financed projects constructed some rural roads given the maintenance responsibilities to local government but local governments felt little ownership of the constructed roads, as they have very little inputs. Because poor maintenance and little ownership feeling, the constructed roads quickly worsened (Alm \& Martinez-Vazquez, 1997).

\subsection{Objectives of the Study}

As said earlier, creation of new municipal bodies is very recent phenomenon and enacted new laws are just in initial stage to apply, so scanning of very limited literature raises some basic research questions, those are still uncovered and that those require updates. In order to answer those research questions, the study sets the following objectives to achieve. The objectives are to:

1) Examine the current (Bangladeshi) municipal revenue strength and expenditure commitment.

2) Understand why building more infrastructure facilities is important for the days to come.

3) Identify and explain the gaps between supply of and demand for infrastructure facilities that attract huge investments for. 


\section{Methodology}

\subsection{Data Collection}

Both primary and secondary source data are used to investigate the research objectives. For FY 2007 through FY 2011, municipal annual budget documents from 28 different municipal bodies across the country are collected on the basis of regional income inequalities and infrastructure development variations. The selected sample seems pretty good representative, as it represents large and small as well as rich and poor in terms of developed and under-developed areas. Municipal annual budget is considered key data source in understanding the current financial capacities in terms of investment needs for infrastructure developments and urban service provisions.

For citizens' satisfaction on municipal infrastructure facilities and other services to know, one hundred and fifty people randomly chosen from five different municipalities have been interviewed. Some relevant native and foreign experts are also consulted to get from them necessary ideas for deriving the ultimate and desired research outcomes. In addition, internet, newspapers, relevant journals and other materials are used to add up the main source information.

\subsection{Method}

By using simple statistical techniques such charts, figures and tables, research results have been figured out. Selected municipal key revenue and expenditure items are analyzed and explained through budgetary ratio and trend analysis.

\subsection{Shortcomings}

It is undeniable that there are some limitations also. As far as time and resource concerned, the study is based on random sampling that does not cover the whole population. Second, generally, access to information in Bangladesh is pretty difficult and moreover, for municipal information there are no reliable databases. Concerned officials are reluctant to provide municipal financial information, whatever they have. Third, municipal accounting and reporting system is not scientific that makes study hard to figure out the exact current financial status and future infrastructure needs. Fourth, municipal authorities have common tendency to make inflated budget estimate in order to attract voter's attention. The respondents interviewed have little knowledge and idea to respond to the set questionnaire. Again, there are some cases found biased and motivated by personal interest.

\section{Results and Discussions}

In view of study objectives set to achieve, the analysis of both primary and secondary data is performed throughout this result section. The municipal budget documents those are analyzed to estimate the results, have been collected for FY 2007 through FY 2011. Starting from urbanization trend, this section continues demonstration and finally ends with telling the state of citizen satisfaction.

\subsection{Urban Growth Trend}

Although Bangladesh is small country in terms of land area, there is great variation in people's income, availability of varied public goods and services, such as education and health care and infrastructure facilities both in urban and rural area. Because rapid population growth compounded by shrink in agricultural land mass, some people who have ability, migrate to foreign countries primarily for jobs and better life and most people having working ability, shift to urban areas within the country. In addition, till now Bangladesh has very low level of urbanization (Siddique, 2005).

Table 1. Urban population trend in Bangladesh (1981-2010)

\begin{tabular}{rrrrrr}
\hline \multirow{2}{*}{ Year } & \multicolumn{3}{c}{} & National Population & Urban Population \\
\cline { 2 - 6 } & National Total $(\mathrm{m})$ & Growth Rate (\%) & Urban Total (m) & Urban (\%) & Urban growth rate (\%) \\
\hline 1981 & 89.90 & 2.40 & 14.10 & 15.70 & 10.60 \\
1991 & 111.45 & 2.17 & 22.45 & 20.15 & 5.40 \\
2001 & 129.25 & 1.48 & 28.80 & 23.39 & 4.20 \\
$2010^{\mathrm{a}}$ & 148.69 & $1.37^{\mathrm{a}}$ & 41.60 & 28.00 & $3.10^{\mathrm{a}}$ \\
\hline
\end{tabular}

\footnotetext{
${ }^{\mathrm{a}} \mathrm{UNICEF}, 2010$. Modified by author based on population census 2011.
} 
Table 1 presents the urban population statistics and urban growth rate for last three decades. In 2010, the people who live in urban area are $28 \%$, which was only $15 \%$ just 30 years before. (Note 12 ) There is high possibility and space that the more people will migrate to the urban area, as the country is developing and that the agriculture labor will transform into the industrial labor. Bangladesh currently records $3.1 \%$ (Note 13), one of the highest urban growth rates in the developing countries. Urbanization is still rapidly going up and 83 million people will live in the urban area by the year 2025. (Note 14) This number is about double of present 41.6 million and will stimulate municipal infrastructure demands. However, municipal infrastructures with other amenities are quite scant to accommodate and provide services to current and forthcoming huge unplanned urbanized people. Thus, investment in developing infrastructure facilities warrants utmost consideration in order for the rapidly growing urban people to ensure citizenry services.

\subsection{Revenue Shares and Trends}

Table 2. Revenue break-up, FY 2007 to FY 2011 (thousand BDT)

\begin{tabular}{|c|c|c|c|c|c|c|c|c|}
\hline Revenues: & 2007-08 & $\%$ & 2008-09 & $\%$ & $2009-10$ & $\%$ & 2010-11 & $\%$ \\
\hline \multicolumn{9}{|l|}{ Own source: } \\
\hline Taxes & 278890 & 20.88 & 336645 & 23.15 & 387373 & 27.05 & 415483 & 24.45 \\
\hline Rates & 126542 & 9.47 & 133603 & 9.19 & 132239 & 9.23 & 151308 & 8.90 \\
\hline Fees & 120840 & 9.05 & 80702 & 5.55 & 56954 & 3.98 & 65501 & 3.85 \\
\hline $\begin{array}{l}\text { Leases, rentals } \\
\& \text { others }\end{array}$ & 221332 & 16.57 & 243682 & 16.75 & 283615 & 19.80 & 302971 & 17.83 \\
\hline $\begin{array}{l}\text { Own-source total } \\
\text { Inter-governmental } \\
\text { Transfers: }\end{array}$ & 747604 & 55.96 & 794632 & 54.64 & 860181 & 60.06 & 935263 & 55.03 \\
\hline Project specific & 446855 & 33.45 & 459502 & 31.59 & 455632 & 31.81 & 570971 & 33.60 \\
\hline $\begin{array}{l}\text { Govt. development } \\
\text { Grants }\end{array}$ & 129162 & 9.67 & 189164 & 13.01 & 103475 & 7.22 & 178650 & 10.51 \\
\hline $\begin{array}{l}\text { Non-development } \\
\text { Grants }\end{array}$ & 5657 & 0.42 & 6826 & 0.47 & 5371 & 0.38 & 6146 & 0.36 \\
\hline Non-governmental & 6590 & 0.49 & 4291 & 0.30 & 7534 & 0.53 & 8401 & 0.49 \\
\hline Total transfers & 588264 & 44.04 & 659783 & 45.36 & 572012 & 39.94 & 764168 & 44.97 \\
\hline Loan & 1961 & 0.15 & 10375 & 0.71 & 3310 & 0.23 & 0 & 0.00 \\
\hline Grand Total & 1335868 & 100.00 & 1454415 & 100.00 & 1432193 & 100.00 & 1699431 & 100.00 \\
\hline
\end{tabular}

Source: Author's budget analysis of 28 municipalities.

As table 2 demonstrates, $55 \%$ is median own-source revenues and $45 \%$ is median central government transfers, while own taxes are $24 \%$ that is lion share of own-source revenues. Of central government transfers, project specific grants constitute $33 \%$ revenues. However, the above percentiles are not good measure to understand real municipal financial needs. Table 4 and 5 actually show per person revenue and expenditure accounts that provide meaningful pictures. The fiscal transfer to total revenue ratio is almost same over the years and in particular drops to $40 \%$ in 2010 . The own source to total revenue ratio hangs between $54 \%$ and $60 \%$ with slight increasing trend. Poor fiscal transfer shows central government limitations over fund allocation for municipal infrastructure development. Own tax to total revenue ratio ranges from $21 \%$ to $27 \%$, which is not encouraging though it shows positive trend. There is space to increase both municipal tax rates and bases. Proper tax assessment and modernized collection system can do a great job for more own source mobilization.

\subsection{Expenditure Shares and Trends}

Table 3. Municipal expenditure allocation, from 2007-08 to 2010-11 (in thousand BDT)

\begin{tabular}{lrrrrrrrr}
\hline Expenditures & $2007-08$ & $\%$ & $2008-09$ & $\%$ & $2009-10$ & $\%$ & $2010-11$ & $\%$ \\
\hline Current Expenditures: & & & & & & & & \\
General establishment & 208052 & 18.66 & 236258 & 18.87 & 276889 & 20.74 & 322428 & 20.18 \\
Education & 11817 & 1.06 & 11432 & 0.91 & 17278 & 1.29 & 15383 & 0.96 \\
Public health \& sanitation & 41064 & 3.68 & 42764 & 3.41 & 45963 & 3.44 & 47915 & 3.00 \\
Tax Collection & 1997 & 0.18 & 2455 & 0.20 & 3996 & 0.30 & 4149 & 0.26 \\
Tree plantation & 252 & 0.02 & 333 & 0.03 & 1095 & 0.08 & 1020 & 0.06 \\
Contribution to social & 6222 & 0.56 & 8545 & 0.68 & 10576 & 0.79 & 12486 & 0.78 \\
\& religious activities & & & & & & & & \\
\hline
\end{tabular}




\begin{tabular}{|c|c|c|c|c|c|c|c|c|}
\hline Water service & 46679 & 4.19 & 53804 & 4.30 & 53985 & 4.04 & 64116 & 4.01 \\
\hline Other & 49742 & 4.46 & 66527 & 5.31 & 58206 & 4.36 & 77910 & 4.88 \\
\hline Total Current Expenditure & 365825 & 32.80 & 422118 & 33.71 & 467988 & 35.06 & 545405 & 34.14 \\
\hline \multicolumn{9}{|l|}{ Development Expenditures: } \\
\hline Infrastructure & 597071 & 53.54 & 672154 & 53.67 & 702211 & 52.61 & 880437 & 55.11 \\
\hline Market Development \& & 93441 & 8.38 & 81401 & 6.50 & 91176 & 6.83 & 78313 & 4.90 \\
\hline \multicolumn{9}{|l|}{ Maintenance } \\
\hline Bus/Truck terminal & 2435 & 0.22 & 9550 & 0.76 & 12790 & 0.96 & 8015 & 0.50 \\
\hline Parks and community centre & 659 & 0.06 & 1146 & 0.09 & 798 & 0.06 & 664 & 0.04 \\
\hline Other capital expenditures & 50816 & 4.56 & 57522 & 4.59 & 47430 & 3.55 & 73575 & 4.61 \\
\hline Total Development expenditure & 744422 & 66.75 & 821773 & 65.62 & 854405 & 64.01 & 1041004 & 65.16 \\
\hline Loan repayment & 4918 & 0.44 & 8443 & 0.67 & 12400 & 0.93 & 11182 & 0.70 \\
\hline Total Expenditures & 1115165 & 100.00 & 1252334 & 100.00 & 1334793 & 100.00 & 1597591 & 100.00 \\
\hline
\end{tabular}

Source: Author's survey of 28 municipalities.

Table 3 shows division of expenditures allocation over FY 2007 to FY 2011. Median current expenditures account for $34 \%$ and that of development expenditures account for $66 \%$. As far as operating efficiency concerned, $34 \%$ current expenditures are moderate, though employees are under-paid and inefficient in respect of technology usage. Development expenditure pretends sound, as it shows $66 \%$ share; however, most shocking news is the poorly per person development spending that can no way fulfill the growing infrastructure facilities demands. This scenario is not expected for at least several reasons. As we know Bangladesh is infrastructure-hungry country and it is evident that there are huge investment demands in this sector. Moreover, rapid urbanization and transformation of agriculture labor to industry labor stimulate urban infrastructure growth. In this circumstance, development budget must go upward with more than $66 \%$ share of total expenditures. We can understand that $66 \%$ share is misleading if median per capita development expenditure is considered.

3.4 Per Capital Spending Capacity

Table 4. Revenues per population (in BDT)

\begin{tabular}{|c|c|c|c|c|c|}
\hline Own source: & $2006-07$ & $2007-08$ & $2008-09$ & 2009-10 & 2010-11 \\
\hline Taxes & 106 & 130 & 152 & 170 & 176 \\
\hline Rates & 45 & 59 & 60 & 58 & 64 \\
\hline Fees & 16 & 56 & 37 & 25 & 28 \\
\hline Leases, rentals & 96 & 103 & 110 & 124 & 128 \\
\hline \multicolumn{6}{|l|}{$\&$ others } \\
\hline Own source total & 263 & 349 & 360 & 377 & 397 \\
\hline \multicolumn{6}{|l|}{ Intergovernmental } \\
\hline \multicolumn{6}{|l|}{ Transfers: } \\
\hline Project specific & 204 & 209 & 208 & 200 & 242 \\
\hline Govt. development & 52 & 60 & 86 & 45 & 76 \\
\hline \multicolumn{6}{|l|}{ Grants } \\
\hline Non-development & 2 & 3 & 3 & 2 & 3 \\
\hline \multicolumn{6}{|l|}{ Grants } \\
\hline Non-governmental & 2 & 3 & 2 & 3 & 4 \\
\hline Total transfers & 260 & 275 & 299 & 251 & 324 \\
\hline Grand Total & 523 & 624 & 658 & 627 & 721 \\
\hline
\end{tabular}

Source: Calculated based on Population Census 2001 and municipal budget documents. 
Table 5. Expenditure per population (in BDT)

\begin{tabular}{|c|c|c|c|c|c|}
\hline Expenditures & $2006-07$ & $2007-08$ & $2008-09$ & $2009-10$ & $2010-11$ \\
\hline \multicolumn{6}{|l|}{ Current Expenditure: } \\
\hline General establishment & 85 & 97 & 107 & 121 & 137 \\
\hline Education & 5 & 6 & 5 & 8 & 7 \\
\hline Public health \& sanitation & 21 & 19 & 19 & 20 & 20 \\
\hline Tax Collection & 1 & 1 & 1 & 2 & 2 \\
\hline Tree plantation & 0 & 0 & 0 & 0 & 0 \\
\hline Contribution to social & 3 & 3 & 4 & 5 & 5 \\
\hline$\&$ religious activities & 0 & 0 & 0 & 0 & 0 \\
\hline Water service & 16 & 22 & 24 & 24 & 27 \\
\hline Other & 18 & 23 & 30 & 25 & 33 \\
\hline Total Current Expenditure & 149 & 171 & 191 & 205 & 231 \\
\hline \multicolumn{6}{|l|}{ Development Expenditures: } \\
\hline Infrastructure & 290 & 279 & 304 & 308 & 373 \\
\hline Market Development \& & 33 & 44 & 37 & 40 & 33 \\
\hline \multicolumn{6}{|l|}{ Maintenance } \\
\hline Bus/Truck terminal & 2 & 1 & 4 & 6 & 3 \\
\hline Parks and community centre & 1 & 0 & 1 & 0 & 0 \\
\hline Other capital expenditures & 24 & 24 & 26 & 21 & 31 \\
\hline Total Development exp. & 350 & 348 & 372 & 374 & 441 \\
\hline Loan repayment & 0 & 2 & 3 & 5 & 4 \\
\hline Total Expenditures & 499 & 521 & 566 & 584 & 677 \\
\hline
\end{tabular}

Source: Calculated based on Population Census 2001

Per capita budget in table 4 and 5 actually depicts real picture of municipal financial capacities in Bangladesh. Simple percentile figures misrepresent the true account of revenue strength and expenditure responsibilities. Table 2 presents that more than $60 \%$ allocated amount are for development purpose that sounds good. However, per capita total revenue figure of around US\$ 9 reveals miserable reality that municipal budgetary capacity is extremely poor compared to both developed and developing countries instances. Developing countries such as India, South Africa, and Namibia have local government spending of US\$799, US\$ 693 and US\$ 402 per person respectively, which is remarkably higher than Bangladesh case. It will be more if it is their municipal figure. The case for developed countries local government spending is US\$2797, for example.

\subsection{Revenue Forecast and Actual}

Revenue forecasting is inevitable; especially transfer revenues for infrastructure development. However, there is large gap between revenue forecast and actual realized revenues.

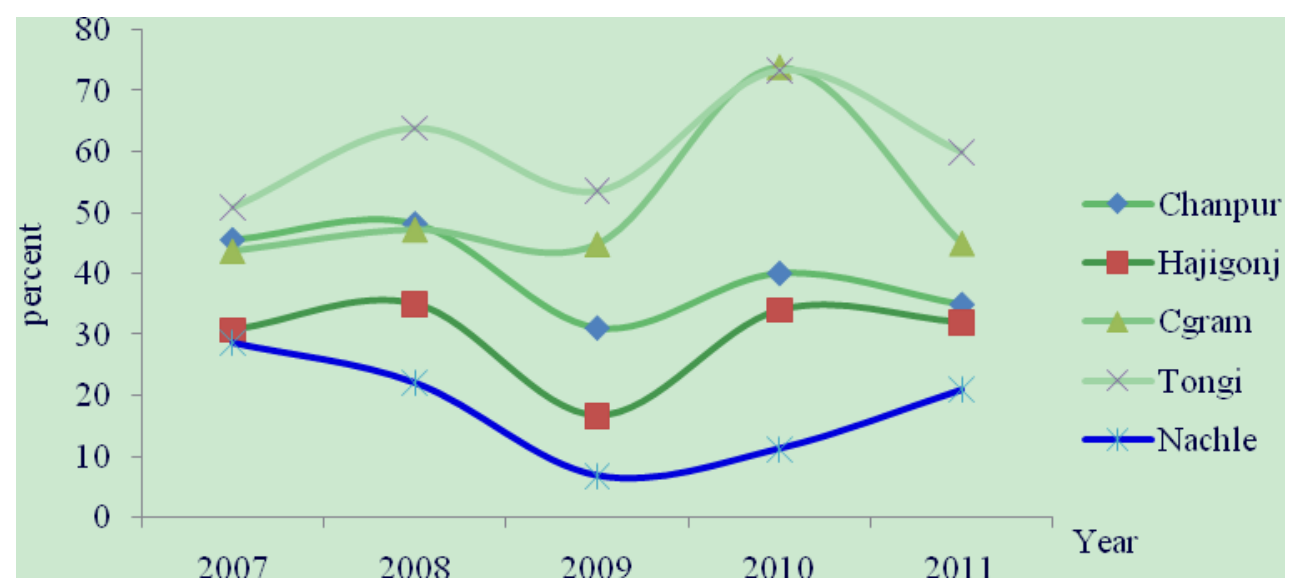

Figure 1. Actual over budgeted total revenues, 2007-2011 


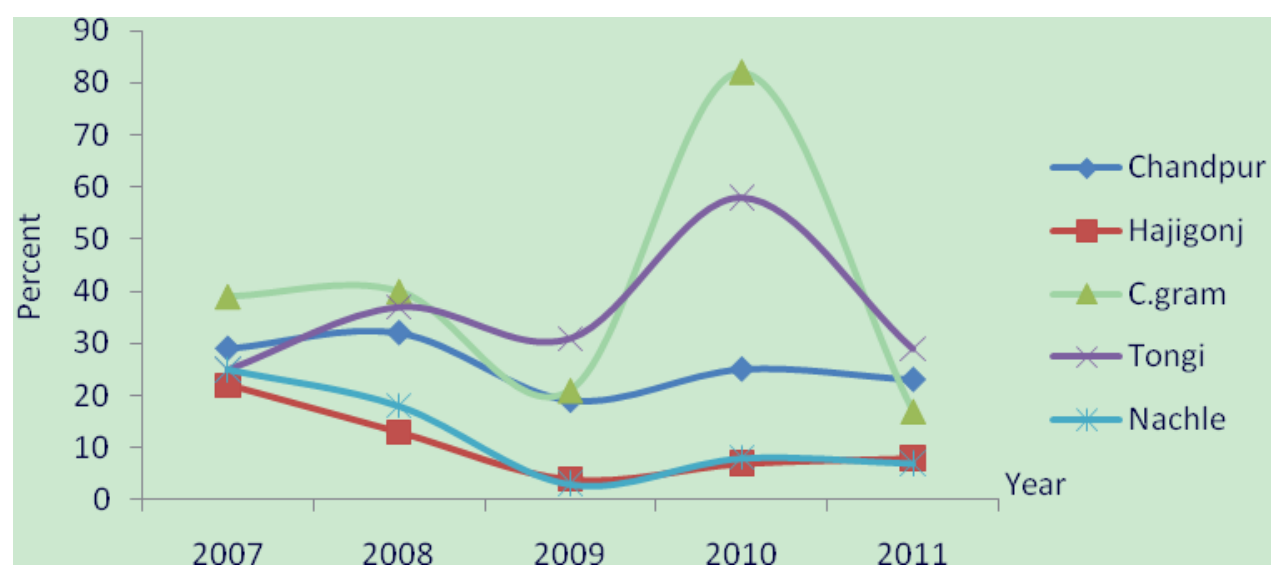

Figure 2. Actual over budgeted transfer revenues (2007-2011)

Figure 1 and 2 displays ratio of actual over budgeted revenues for FY 2007 through FY 2011. The key points to note from figures that, in respect of actual revenue collection over budget estimate, there is dispersion across five municipalities. Most important point to note is that variations of actual revenues realized range between $7 \%$ and $74 \%$, which actually shows two things: first, municipalities vary greatly and, second, there are huge gap between revenue estimate and actual revenue realization.

\subsection{Citizen Satisfaction}

Citizens' satisfaction is assessed through questionnaire survey and participants are asked to learn their satisfaction level on the services municipalities practically provide, as table 6 demonstrates.

Table 6. Citizens' satisfaction on key municipal services

\begin{tabular}{|c|c|c|c|c|}
\hline \multirow{2}{*}{ Service Type } & \multicolumn{4}{|c|}{ Satisfaction level (Note 15) } \\
\hline & Satisfied & Somewhat satisfied & Dissatisfied & Don't know \\
\hline $\begin{array}{l}\text { Infrastructures (roads, culverts, bridges, bus terminal, market and so } \\
\text { on) }\end{array}$ & & & $\sqrt{ }$ & \\
\hline Cleanliness & & & $\sqrt{ }$ & \\
\hline Drainage and sewerage & & & $\sqrt{ }$ & \\
\hline Mosquito control & & & $\sqrt{ }$ & \\
\hline Water supply & & & $\sqrt{ }$ & \\
\hline Street lighting & & & $\sqrt{ }$ & \\
\hline Sanitation \& waste disposal & & & $\sqrt{ }$ & \\
\hline Parks \& recreation & & & $\sqrt{ }$ & \\
\hline Complaints settlement & & & $\sqrt{ }$ & \\
\hline Overall service rating & & & $\sqrt{ }$ & \\
\hline
\end{tabular}

Source: Questionnaire survey of 150 service receivers from five municipalities.

Services include infrastructure facilities, water services, sanitation and other public health issues, cleanliness and so on. Total one hundred and fifty people are interviewed from five different municipalities. More than $70 \%$ respondents interviewed are somehow dissatisfied with services they receive including infrastructure facilities. In addition, some local government experts are also consulted to know why the municipalities fail to provide satisfactory services. They said most of the urban areas are declared 'municipality' and later upgraded under political consideration, not considering the fact that municipalities have capacities and resources to ensure infrastructure facilities and other services. The author also finds in the interview that public representatives of the municipal bodies are, in most cases, afraid of losing popularity for mobilizing resources through imposing taxes. So municipalities have incapacity to satisfy people through services. 


\section{Conclusion and Policy Issues}

The study attempts to find (Bangladeshi) municipal financial capabilities for building infrastructure facilities, to find why infrastructure facilities are urgent to consider and to identify gap between infrastructure facilities demand and supply. By analyzing municipal budget data, urban population trend and primary data that have been collected, the study finds municipalities have very poor revenue strength (less than US\$ 10 per person) that is to spend for huge expenditure commitment, as more and more infrastructure facilities are required for developing country like Bangladesh. Besides, the central transfers, which are actually expended to building infrastructures are almost standstill over the years and even sometimes decline. Total revenues received have wide dispersion and have $93 \%$ shortage of budgeted revenues at worst case and $27 \%$ shortage at the best case among the municipalities. By 2025, at 3.1\% urban growth rate, current urban population will double, which indicates far more demand for infrastructures that will ultimately widen the gap even further. Around $70 \%$ respondents interviewed are dissatisfied with the service qualities and quantities they receive. In light of the above findings, the study suggests that policy makers have spaces to work in respect of finding alternate long term infrastructure financing mechanism that can enhance many-folds the municipal spending capacities for infrastructure development and quality service delivery. In other words, the infrastructure demand gap will attract investment funds if policy supports are ensured from government.

It would be great if the study would have covered total municipal financial and infrastructure facilities data. Given the limitations, future researchers can conduct an inclusive and in-depth study to find a concrete and unique model for infrastructure financing mechanisms that best fit in supplying long term investment for Bangladeshi municipalities. Research can also focus on financial markets' readiness as to how they will behave if municipalities try to raise capital from them.

\section{Acknowledgements}

I would like to thank Professor Mizuki Nakama who supervises and gives me insightful suggestions during writing this article. Thanks also to Professor James Alm who I red helped me acquire knowledge on municipal finance and thus writing this article. I also thank twenty eight municipal authorities who have provided budget documents, the people I interviewed to know their opinions about municipal service satisfactions, and local government experts who shared their knowledge and ideas about municipal finance of Bangladesh.

\section{References}

Alm, J. (2010). Municipal Finance of Urban Infrastructure, Knowns and Unknowns. Wolfenson Center for Development, Working Paper. from http://www.eSocialSciences.com/data/articles/Document1186201050.8622248.pdf

Alm, J., \& Martinez, V. J. (1997). Bangladesh municipal finance management sector study. Infrastructure Operations Divisions, Country Department 1, South Asia Region. Washington, DC: The World Bank.

Aoki, I. (2008). Decentralization and Intergovernmental Finance in Japan. PRI Discussion Paper Series (No. 08A-04). Policy Research Institute, Ministry of Finance, Japan.

Bahl, R., \& Bird, R. (2008). Sub-national Taxes in Developing Countries: The Way Forward. Public Budgeting \& Finance, 28, 1-25. http://dx.doi.org/10.1111/j.1540-5850.2008.00914.x

Bahl, R. (1999). Fiscal Decentralization as Development Policy. Public Budgeting \& Finance, 19(2), 59-75. http://dx.doi.org/10.1046/j.0275-1100.1999.01163.x

Bahl, R., \& Linn, J. F. (1992). Urban Public Finance in Developing Countries. New York: Oxford University Press.

Bangladesh Bureau of Statistics. (2010). Home page, Population census 2001, GoB. Retrieved from http://www.bbs.gov.bd/PageReportLists.aspx?PARENTKEY=41

Billand, J. C. (2005). Municipal Finance: Increasing local Government Resources to Fund Multi-Sectoral Facilities. Washington, DC: USA. Retrieved from http://www.tcgillc.com/tcgidocs/paper_billand.pdf

Bird, R. M. (1993). Threading the Fiscal Labyrinth: Some Issues in Fiscal Decentralization. National Tax Journal, 46(2), 207-227.

Chowdhury, A. I. (2004). Instruments of Local Financial Reform and their Impact on Service Delivery. Centre for Urban Studies, Dhaka. Retrieved from http://saneinetwork.net/Files/06_05.pdf

Dirie, I. (n.d.). Municipal Finance: Innovative Resourcing for Municipal Infrastructure and Service Provision. CLG International LLC, Washington, DC. 
Fox, W. F., \& Menon, B. (2008). Decentralization in Bangladesh: Change has been illusive. working paper 08-29. International Studies Program, Andrew Young School of Policy Studies, Georgia State University.

Mallick, B. (2004). Local Government: Local People's Institution-A compilation on Local Government issue. Development Publishing House, Dhaka.

Oates, W. E. (1999). An Essay on Fiscal Federalism. Journal of Economic Literature, 37(September), 1120-1149. http://dx.doi.org/10.1257/jel.37.3.1120

Oates, W. E. (1993). Fiscal Decentralization and Economic Development. National Tax Journal, 46(2), 237-243.

Siddique, K. (2005). Local Government in Bangladesh. Dhaka: The University Press Limited.

Slater, D. (1989). Territorial power and peripheral state: The issue of decentralization, development and change.

Slater, R. (1997). Approaches to Strengthening Local Government: Lessons from Sri Lanka. Public $\begin{array}{llll}\text { Administration } \text { and } & \text { Development, }\end{array}$ http://dx.doi.org/10.1002/(SICI)1099-162X(199705)17:2<251::AID-PAD932>3.0.CO;2-2

UNICEF. (2010). Home page. from http://www.unicef.org/infobycountry/bangladesh_bangladesh_statistics.html

World Bank. (2007). Bangladesh: Strategy for Sustained Growth.

\section{Notes}

Note 1. UNICEF, 2010.

Note 2. Choudhury, 2004.

Note 3. Local Government (Paurashava) Act, 2009.

Note 4. The Local Government (Paurashava) Act 2009, Article-50 and 51; The Local Government (Upazila Parishad) Act, 1998.

Note 5. Local Government (Paurashava) Act 2009.

Note 6. Siddique, 2005, pp. 134; Mallick, 2004, pp. 49. The municipalities those have average annual own sourcerevenues of BDT 6 million in three year's period are classified as "A" category pourasova. 'B' category pourasova shall have own source income of between BDT 2.5 million and BDT 6 million and ' $\mathrm{C}$ ' category pourasove shall have own source income of between BDT 1 million and BDT 2.5 million in three years period. However, the amount of own source income is subject to change by the government order from time to time.

Note 7. Author experiences when working in the local government level and noticing relevant government rules.

Note 8. The nine are Dhaka, Chittagong, Rajshahi, Khulna, Barishal, Syllet, Rangpur, Narayangonj and Comilla city corporations. The last three are declared in 2011 as city corporation.

Note 9. Population Census 1981, 1991 and 2001, Government of Bangladsh; b. Statistical Pocket Book 2009, GoB; c. UNICEF, 2010.

Note 10. Local Government (Paurashava) Act, 2009, Second schedule (article 50-71).

Note 11. Dirie, I. (n.d.). Municipal Finance: Innovative Resourcing for Municipal Infrastructure and Service Provision, CLG International LLC, Washington, DC.

Note 12. Bangladesh Bureau of Statistics (BBS), 2001 and 2011.

Note 13. 3.1\% urban growth rate for 2011 to 2021 is estimated by UNICEF in 2010.

Note 14. Based on 2001 population census and by using UNICEF's 3.1 urban growth rate.

Note 15. Citizens' satisfaction on each category is assessed based on maximum respondent's opinion that favors the issue. 